\title{
Phase I Study of LFA102 in Patients With Advanced Breast Cancer or Castration-resistant Prostate Cancer
}

\author{
HIRONOBU MINAMI $^{1}$, YUICHI ANDO ${ }^{2}$, KENJI TAMURA $^{3}$, TAKESHI TAJIMA $^{4}$ and RANDI ISAACS ${ }^{5}$ \\ ${ }^{1}$ Medical Oncology and Hematology, Kobe University Graduate School of Medicine, Kobe, Japan; \\ ${ }^{2}$ Clinical Oncology and Chemotherapy, Nagoya University Hospital, Nagoya, Japan; \\ ${ }^{3}$ Breast and Medical Oncology, National Cancer Center Hospital, Tokyo, Japan; \\ ${ }^{4}$ Novartis Pharma K.K., Tokyo, Japan; \\ ${ }^{5}$ Novartis Pharmaceuticals Corporation, East Hanover, NJ, U.S.A.
}

\begin{abstract}
Background/Aim: The prolactin receptor (PRLR) is implicated in the tumorigenesis of breast and prostate cancers where it drives cell proliferation, survival, and migration. LFA102 is a humanized monoclonal antibody against PRLR with promising preclinical antitumor activity. To determine the maximum tolerated dose or a recommended dose, and to delineate the pharmacokinetic profile of LFA102 in Japanese patients, we conducted a phase I study. Patients and Methods: LFA102 was intravenously infused every 4 weeks to patients with advanced breast or castration-resistant prostate cancer, and the dose increased from 3 to $40 \mathrm{mg} / \mathrm{kg}$. Results: Fourteen patients were treated, and toxicities were reported in $9(64 \%)$ patients. They were all grade 1 or 2, and the most frequently observed toxicity was nausea (3 patients, 21\%). No dose-limiting toxicities were observed. LFA102 did not show antitumor activity as a single agent. Conclusion: Treatment with LFA102 was well tolerated.
\end{abstract}

Prolactin mediates its physiological effects through interactions with the prolactin receptor (PRLR). Following binding to PRLR, prolactin activates a wide array of downstream signals, including JAK2/STAT5, JAK1/STAT3, SRC, and FAK pathways leading to PI3K/AKT and RAF/MEK/ERK activation. These signaling cascades trigger cell proliferation, survival, migration, differentiation, and angiogenesis (1). Preclinical data show that mammary gland-

This article is freely accessible online.

Correspondence to: Hironobu Minami, MD, D.Med.Sci., Medical Oncology and Hematology, Kobe University Graduate School of Medicine, 7-5-1 Kushunoki-cho, Chuo-ku, Kobe 650-0017, Japan. Tel: +81783825820, e-mail: hminami@med.kobe-u.ac.jp (ClinicalTrials.gov number: NCT01610050)

Key Words: Prolactin receptor, breast cancer, prostate cancer. or prostate-specific expression of prolactin in transgenic mice increases the incidence of breast and prostate tumors, respectively (2-4). In the clinic, PRLR overexpression is observed in many malignancies, including breast, prostate, ovarian, colorectal, and pancreatic cancers (5-8). Indeed, $95 \%$ of breast and prostate cancers are PRLR-positive $(9,10)$ and high levels of prolactin in the blood have been correlated with increased risk and poor prognosis in breast cancer (1113). In prostate cancer, prolactin expression has been correlated with phosphorylation of Stat5 (a key mediator of prolactin signaling), high Gleason scores and unfavorable prognosis $(14,15)$.

Prolactin protein is synthesized and secreted from the pituitary gland and from extrapituitary sites including breast and prostate tissues. The overexpression of PRLR in breast and prostate cancers stimulates their growth and contributes to their aggressiveness by autocrine and paracrine mechanisms $(3,16$, 17). Furthermore, endogenous prolactin increased the constitutive tyrosine phosphorylation of HER 2 in a breast cancer cell line, leading to enhanced growth through the RAS-MAPK pathway (18). Therefore, targeting the prolactin signaling pathway is an attractive endocrine therapeutic strategy.

LFA102 is a humanized $\operatorname{IgG} 1 / \mathrm{K}$ monoclonal antibody (mAb) against PRLR. The antibody neutralizes all prolactin-induced intracellular signaling pathways examined in vitro, including those mediated through Stat5, Akt, and Erk1/2. Furthermore, LFA102 induces antibody-dependent cell-mediated cytotoxicity in vivo, and inhibits the growth of prolactin-dependent cell lines engineered to express human PRLR and of mammary tumors induced by dimethylbenz $[\alpha]$ anthracene (19). LFA102 also blocks prolactin-induced proliferation in human breast cancer cell lines, including MCF7 and T47D (19).

In the present study, we aimed to determine the maximum tolerated dose (MTD) or a recommended dose of LFA102, and to investigate safety, pharmacokinetics, and preliminary evidence of anti-tumor activity in Japanese patients. We therefore conducted a phase I open-label multi-center dose- 
escalation study in patients with advanced breast cancer or castration-resistant prostate cancer (CRPC). This study was conducted in parallel with a global phase I study in the US and European countries in patients with PRLR-positive metastatic breast cancer or CRPC (20).

\section{Patients and Methods}

Eligibility criteria. Patients with histologically/cytologically confirmed advanced breast cancer or CRPC, age $\geq 18$ years, Eastern Cooperative Oncology Group (ECOG) performance status 2 or better, adequate bone marrow, liver and renal functions, and no anticancer drug therapies for $\geq 4$ weeks ( 6 weeks for nitrosourea, or mitomycin-C) were enrolled.

Prostate cancer patients must have had detectable metastasis and should have been castrated either surgically via orchiectomy or chemically via the use of luteinizing hormone-releasing hormone (LH-RH) agonists or antagonists. Progressive disease must also have been documented. For breast cancer, progression following the last line of standard treatment and at least one measurable lesion as defined by Response Evaluation Criteria in Solid Tumors (RECIST) version 1.1 were required.

The main exclusion criteria were untreated and/or symptomatic metastatic central nervous system disease, other active malignancies or clinically significant diseases, prior treatment with any antiPRLR antagonist, major surgery within 28 days, radiotherapy within 2 weeks, chronic steroid therapy of more than $10 \mathrm{mg} /$ day prednisone, and pregnant or nursing women.

Study treatment and design. LFA102 was administered once every 4 weeks (28-day cycle) as an intravenous infusion over $2 \mathrm{~h}$. Treatment was continued until disease progression, unacceptable toxicity, or patient withdrawal.

A Bayesian logistic regression model (BLRM) with an overdose control principle was used to support the decision of dose escalation and determination of the MTD or a recommended dose $(21,22)$, and each cohort of patients consisted of 3 to 6 evaluable patients. Provisional dose levels were $3,10,20$ and $40 \mathrm{mg} / \mathrm{kg}$, and the starting dose of $3 \mathrm{mg} / \mathrm{kg}$ was based on information on the highest non-severely toxic dose in cynomolgus monkeys. Dose-limiting toxicities (DLTs) observed during the first cycle of treatment with LFA102 were considered at dose escalation.

The dose was escalated until the MTD was reached. The MTD was defined as the highest dose not causing medically unacceptable DLTs in more than $33 \%$ of the treated patients in the first cycle of the treatment. The recommended dose was determined in consideration of all clinical data obtained in the entire study.

The study was approved by the ethics committees of each participating institution and conducted in accordance with the International Conference on Harmonization Good Clinical Practice Guidelines as well as the Declaration of Helsinki. All patients provided written informed consent.

Definition of DLTS. Toxicities were graded according to the National Cancer Institute's Common Terminology Criteria for Adverse Events (CTCAE) version 4.03. DLT was defined as grade 4 neutropenia for $>5$ consecutive days, febrile neutropenia, $\geq$ grade 3 thrombocytopenia with clinical bleeding or requiring platelet transfusion, $\geq$ grade 4 thrombocytopenia, $\geq$ grade 3 increase in
Table I. Patient characteristics.

\begin{tabular}{|c|c|c|c|}
\hline & $\begin{array}{l}\text { Breast cancer } \\
\quad(\mathrm{n}=7)\end{array}$ & $\begin{array}{c}\text { Prostate cancer } \\
\qquad(\mathrm{n}=7)\end{array}$ & $\begin{array}{l}\text { Total } \\
(n=14)\end{array}$ \\
\hline \multicolumn{4}{|l|}{ Age (years) } \\
\hline Median (range) & $71(52-75)$ & $66(57-71)$ & $67.5(52-75)$ \\
\hline \multicolumn{4}{|l|}{ Gender } \\
\hline Female/Male & $7 / 0$ & $0 / 7$ & $7 / 7$ \\
\hline \multicolumn{4}{|l|}{ Weight (kg) } \\
\hline Mean \pm SD & $52.3 \pm 7.3$ & $68.2 \pm 9.1$ & $60.2 \pm 11.4$ \\
\hline \multicolumn{4}{|l|}{ Performance status (n) } \\
\hline $0 / 1 / 2$ & $3 / 3 / 1$ & $6 / 1 / 0$ & $9 / 4 / 1$ \\
\hline \multicolumn{4}{|l|}{ Hormone receptor } \\
\hline$+/-$ & $6 / 1$ & NA & NA \\
\hline \multicolumn{4}{|l|}{ HER 2} \\
\hline \multicolumn{4}{|l|}{ Previous treatment } \\
\hline Surgery & 6 & 0 & 6 \\
\hline Primary disease & 6 & 0 & 6 \\
\hline Metastatic disease & 1 & 0 & 1 \\
\hline Radiotherapy & 5 & 3 & 8 \\
\hline Primary disease & 1 & 0 & 1 \\
\hline Metastatic disease & 4 & 3 & 7 \\
\hline Hormone therapy & 6 & 7 & 13 \\
\hline Primary disease & 6 & 0 & 6 \\
\hline Metastatic disease & 5 & 7 & 12 \\
\hline Chemotherapy & 7 & 6 & 13 \\
\hline Primary disease & 7 & 0 & 7 \\
\hline Metastatic disease & 7 & 6 & 13 \\
\hline \multicolumn{4}{|l|}{$\begin{array}{l}\text { No. of chemotherapy } \\
\text { regimens for } \\
\text { metastatic disease }\end{array}$} \\
\hline $1-2$ & 1 & 5 & 6 \\
\hline $3-4$ & 3 & 1 & 4 \\
\hline $5-$ & 3 & 0 & 3 \\
\hline
\end{tabular}

serum creatinine or total bilirubin, grade 2 total bilirubin elevation in combination with grade 3 AST or ALT elevation, grade 3 elevation of AST/ALT for $>7$ days, grade 4 AST/ALT elevation, symptomatic serum amylase/lipase elevation or pancreatitis, $\geq 72 \mathrm{~h}$ of grade 3 fatigue, $\geq$ grade 3 other non-hematological toxicities, and discontinuation from study drug administration (including dose delay of $>4$ weeks from the next scheduled treatment).

Concomitant treatment. Patients with prostate cancer under treatment with LH-RH analogues or antagonists were required to continue these treatments to maintain the castrated status. Daily use of $10 \mathrm{mg}$ prednisone (or equivalent) or lower dose was permitted. Patients were not allowed to take medications that could affect prolactin level, including drugs such as butyrophenones, bromocriptine, clomipramine, cabergoline, terguride, phenothiazines, risperidone, and thioxanthenes $(23,24)$.

Assessments. Safety was assessed by grading toxicities based on the CTCAE. For efficacy assessment, contrast-enhanced CT or MRI imaging was performed every 8 weeks and efficacy was evaluated according to the RECIST version 1.1 in patients with breast cancer. In patients with CRPC, contrast-enhanced CT or MRI imaging was 
Table II. Toxicities.

\begin{tabular}{|c|c|c|c|c|c|c|c|c|c|c|}
\hline & \multicolumn{2}{|c|}{$\begin{array}{c}3 \mathrm{mg} / \mathrm{kg} \\
(\mathrm{n}=3)\end{array}$} & \multicolumn{2}{|c|}{$\begin{array}{c}10 \mathrm{mg} / \mathrm{kg} \\
(\mathrm{n}=4)\end{array}$} & \multicolumn{2}{|c|}{$\begin{array}{c}20 \mathrm{mg} / \mathrm{kg} \\
(\mathrm{n}=4)\end{array}$} & \multicolumn{2}{|c|}{$\begin{array}{c}40 \mathrm{mg} / \mathrm{kg} \\
(\mathrm{n}=3)\end{array}$} & \multicolumn{2}{|c|}{$\begin{array}{c}\text { Total } \\
(\mathrm{n}=14)\end{array}$} \\
\hline & \multicolumn{2}{|c|}{ Grade } & \multicolumn{2}{|c|}{ Grade } & \multicolumn{2}{|c|}{ Grade } & \multicolumn{2}{|c|}{ Grade } & \multicolumn{2}{|c|}{ Grade } \\
\hline & $1 / 2$ & $3 / 4$ & $1 / 2$ & $3 / 4$ & $1 / 2$ & $3 / 4$ & $1 / 2$ & $3 / 4$ & $1 / 2$ & $3 / 4$ \\
\hline Nausea & 0 & 0 & 2 & 0 & 1 & 0 & 0 & 0 & 3 & 0 \\
\hline Dry skin & 1 & 0 & 0 & 0 & 0 & 0 & 1 & 0 & 2 & 0 \\
\hline Peripheral edema & 1 & 0 & 0 & 0 & 1 & 0 & 0 & 0 & 2 & 0 \\
\hline Anemia & 0 & 0 & 0 & 0 & 0 & 0 & 1 & 0 & 1 & 0 \\
\hline Arthralgia & 1 & 0 & 0 & 0 & 0 & 0 & 0 & 0 & 1 & 0 \\
\hline Bilirubin increased & 0 & 0 & 0 & 0 & 1 & 0 & 0 & 0 & 1 & 0 \\
\hline Decreased appetite & 0 & 0 & 0 & 0 & 1 & 0 & 0 & 0 & 1 & 0 \\
\hline Dizziness & 0 & 0 & 0 & 0 & 1 & 0 & 0 & 0 & 1 & 0 \\
\hline Dysgeusia & 0 & 0 & 0 & 0 & 1 & 0 & 0 & 0 & 1 & 0 \\
\hline Fatigue & 0 & 0 & 0 & 0 & 1 & 0 & 0 & 0 & 1 & 0 \\
\hline Peripheral neuropathy & 1 & 0 & 0 & 0 & 0 & 0 & 0 & 0 & 1 & 0 \\
\hline Proteinuria & 0 & 0 & 1 & 0 & 0 & 0 & 0 & 0 & 1 & 0 \\
\hline Pyrexia & 0 & 0 & 0 & 0 & 1 & 0 & 0 & 0 & 1 & 0 \\
\hline Stomatitis & 0 & 0 & 0 & 0 & 0 & 0 & 1 & 0 & 1 & 0 \\
\hline Weight decreased & 0 & 0 & 0 & 0 & 1 & 0 & 0 & 0 & 1 & 0 \\
\hline
\end{tabular}

performed every 12 weeks, and PSA was measured every 4 weeks. Efficacy was evaluated using the Prostate Cancer Clinical Trials Working Group (PCWG2) response criteria (25).

Pharmacokinetics. For pharmacokinetic investigation, blood was obtained at baseline, 1, 2 (end of infusion), 2.25, 4, 8, 24, 48, 72, $168,240,336$, and $504 \mathrm{~h}$ after the start of infusion of cycle 1 , as well as before infusion of each cycle. Serum concentrations of free LFA102 were measured using a validated assay method with a LLOQ of $200 \mathrm{ng} / \mathrm{ml}$.

\section{Results}

Demographic and background characteristics. A total of 14 patients were enrolled and treated with LFA102 at doses ranging from 3 to $40 \mathrm{mg} / \mathrm{kg}$ (Table I). Among seven patients with breast cancers, one patient had triple-negative breast cancer (negative for estrogen receptor, progesterone receptor, and HER2) and one patient had breast cancer positive for the three markers. For metastatic disease, all patients had been treated with hormonal therapy except for the patient with triple-negative breast cancer. Patients with breast cancer had been heavily treated with chemotherapy (Table I).

The median duration of treatment was 12.35 weeks (range $=4.0-45.1$ weeks) across all doses, and six patients (43\%) were treated for $\geq 14$ weeks. No anti-tumor activity was evident.

Safety. LFA102 was safe and well tolerated. Of 14 patients, drug-related toxicities were reported in $9(64 \%)$ patients, and the most frequently observed toxicities were nausea (3 patients, $21 \%$ ) followed by dry skin and peripheral edema ( 2 patients each, 14\%; Table II). All toxicities were grade 1 or 2 in severity. The incidence of toxicities was generally comparable across all LFA102 doses.

Most of the adverse events regardless of the relationship with LFA102 were grade 1 or 2 . Grade 3 or 4 adverse events were reported in 3 patients $(21 \%)$, and composed of increased amylase level, dyspnea, lymphocytopenia, peripheral motor neuropathy and tumor pain occurring in one patient each. None of these grade 3 or 4 adverse events were suspected to be related to LFA102. Two patients (14\%) reported serious adverse events. These were nausea, vomiting, urinary tract infection, and pathological fracture. All of these events were grade 2 in severity and none of them were considered to be related to LFA102.

Overall, one patient (7\%) discontinued the study drug due to nausea and vomiting; neither illness was considered to be related to the study drug. No dose adjustment or interruptions were precipitated by adverse events. No DLT was observed up to $40 \mathrm{mg} / \mathrm{kg}$, and the MTD was not reached.

Pharmacokinetics. Exposure to LFA102 increased almost dose-proportionally with dose escalation, and inter-individual variability of exposure to LFA102 at each dose was small with the coefficients of variation of AUC and Cmax ranging from 9 to 24\% (Table III). Median half-life at each dose ranged from 6.6 to 12.1 days, which is relatively short for an antibody drug. 
Table III. Pharmacokinetic parameters.

\begin{tabular}{|c|c|c|c|c|}
\hline & $\begin{array}{c}3 \mathrm{mg} / \mathrm{kg} \\
(\mathrm{n}=3)\end{array}$ & $\begin{array}{c}10 \mathrm{mg} / \mathrm{kg} \\
(\mathrm{n}=4)\end{array}$ & $\begin{array}{c}20 \mathrm{mg} / \mathrm{kg} \\
(\mathrm{n}=4)\end{array}$ & $\begin{array}{c}40 \mathrm{mg} / \mathrm{kg} \\
(\mathrm{n}=3)\end{array}$ \\
\hline \multicolumn{5}{|c|}{$\mathrm{AUC}_{\text {last }}(\mu \mathrm{g} / \mathrm{ml} \times$ day $)$} \\
\hline Mean \pm SD & $408.1 \pm 99.9$ & $1628 \pm 250$ & $3631 \pm 389$ & $5674 \pm 507$ \\
\hline Median & 429.6 & 1640 & 3522 & 5438 \\
\hline (range) & $(299.2-495.4)$ & $(1328-1903)$ & $(3290-4191)$ & $(5328-6256)$ \\
\hline \multicolumn{5}{|c|}{ Clearance $(\mathrm{ml} / \mathrm{day} / \mathrm{kg})$} \\
\hline Mean \pm SD & $6.2 \pm 0.6^{*}$ & $5.9 \pm 0.9$ & $4.7 \pm 0.4$ & $6.4 \pm 0.7 *$ \\
\hline Median & $6.2^{*}$ & 5.7 & 4.7 & $6.4^{*}$ \\
\hline (range) & $(5.8-6.6)^{*}$ & $(5.0-7.0)$ & $(4.2-5.2)$ & $(5.9-6.9)^{*}$ \\
\hline \multicolumn{5}{|l|}{$\mathrm{C}_{\max }(\mu \mathrm{g} / \mathrm{ml})$} \\
\hline Mean \pm SD & $70.2 \pm 8.1$ & $257.8 \pm 37.6$ & $572.8 \pm 76.6$ & $1089 \pm 227$ \\
\hline Median & 65.7 & 272.5 & 542.5 & 1210 \\
\hline (range) & $(65.3-79.6)$ & $(202-284)$ & $(520-686)$ & $(827-1230)$ \\
\hline \multicolumn{5}{|l|}{$\mathrm{T}_{\max }(\mathrm{h})$} \\
\hline Median & 2.3 & 3.2 & 4.0 & 4.0 \\
\hline (range) & $(2.0-4.0)$ & $(2.3-7.9)$ & $(2.0-4.0)$ & $(2.3-24)$ \\
\hline \multicolumn{5}{|l|}{$\mathrm{T}_{1 / 2}$ (day) } \\
\hline Median & 6.6 & 7.4 & 12.1 & 12.1 \\
\hline (range) & $(6.1-7.7)$ & $(6.5-9.1)$ & $(10.3-12.9)$ & $(7.6-21.2)$ \\
\hline \multicolumn{5}{|l|}{$\mathrm{Vz}(\mathrm{ml} / \mathrm{kg})$} \\
\hline Mean \pm SD & $64.2 \pm 12.0^{*}$ & $64.7 \pm 15.8$ & $80.6 \pm 12.1$ & $89.6 \pm 19.5^{*}$ \\
\hline Median & $64.2 *$ & 64.7 & 84.8 & $89.6^{*}$ \\
\hline (range) & $(55.7-72.6)^{*}$ & $(50.2-79.2)$ & $(62.9-89.8)$ & $(75.8-103.3)^{*}$ \\
\hline
\end{tabular}

$* \mathrm{n}=2$.

\section{Discussion}

Toxicities associated with LFA102 were mild and no grade 3 or greater toxicities were observed; the most common toxicity was nausea. The dose of LFA102 was increased to $40 \mathrm{mg} / \mathrm{kg}$ in this study without observations of DLTs, and the MTD was not reached. Similarly, in a parallel phase I study of LFA102 conducted in the US and Europe in which the dose was escalated to $60 \mathrm{mg} / \mathrm{kg}$, no DLTs were observed and the MTD was not reached (20).

A dose-proportional increase in exposure to LFA102 was observed with dose escalation, and the inter-individual variability of pharmacokinetics was small. Exposure to LFA102 was also dose-proportional in the parallel phase I study (20), and there was no evidence of inter-ethnic differences in pharmacokinetics between Japanese patients and those in the US and Europe.

Dose escalation was halted because no responses were observed either in this study or in the parallel phase I study. Preclinical evidence suggests that prolactin signaling has an important role in breast and prostate cancer, and LFA102 treatment did elicit tumor shrinkage in an in vivo breast cancer model (19). The situation in the clinic is clearly different, since LFA102 seemed to have no efficacy as a single agent in patients with advanced breast cancer or CRPC.
LFA102 was administered every 4 weeks in both phase I studies, and had a half-life of 7 to 12 days, which is relatively short for an antibody drug. We infer that more frequent dosing of LFA102 might be necessary for antitumor efficacy. However, in a preclinical in vivo breast cancer model, LFA102 suppressed tumor growth with regression observed in $20 \%$ of tumors, and phosphorylation of Stat5 in cancer cells was inhibited at an LFA102 serum concentration of $70 \mu \mathrm{g} / \mathrm{ml}$ or higher (19). In our phase I study, the Cmax of LFA102 was much higher than this which, given its halflife, should have been sufficient to suppress Stat5 phosphorylation in most patients during the treatment courses.

In the parallel phase I study, serum prolactin level was increased in a dose-dependent manner by LFA102 treatment, suggesting prolactin signaling was suppressed in patients (20). However, the pituitary gland is the main source of prolactin, and it is unclear whether LFA102 suppresses prolactin signaling in the tumor tissue. It is possible that the distribution of LFA102 to cancer tissues in patients was limited.

Potential explanations for the lack of efficacy might include the possibility that prolactin is not an oncogenic driver in human breast or prostate cancer, that other pathways are activated in order to bypass the effect of PRLR inhibitors, or that prolactin-independent signaling pathways 
are upregulated in order to maintain tumors. Although many preclinical studies have demonstrated that PRLR activation can promote cancer cell proliferation and survival $(1,16$, 17), the clinical effect of cancer cell-derived prolactin on patient outcome is controversial in recent reports. High PRLR expression was associated with a shorter time to bone metastasis in one study of patients with breast cancer (26), whereas other reports showed that it was associated with better relapse-free survival and longer distant metastasis-free survival $(27,28)$. Recently it has also been reported that PRLR is a marker of good prognosis in triple-negative breast cancer patients who underwent surgery (29). In line with these reports, expression/activation of Stat5a, an effector molecule in prolactin signaling, was positively correlated with an increased level of histologic differentiation in breast cancer tissues and with a favorable prognosis (30). Thus, whereas prolactin may contribute to the initial development of breast cancer, it may also have context-specific roles in restricting the metastatic potential of certain tumors (31).

Furthermore, prolactin potently inhibits growth factorinduced proliferation of breast cancer cells (32). Preclinical experiments indicate that blocking prolactin signaling leads to activation of mitogen-activated protein kinase and transforming growth factor- $\beta /$ Smad signaling pathways (33), and concomitant expression of prolactin and TGF- $\beta$ receptors is associated with a less aggressive phenotype and favorable patient outcome (34). Potential agonistic as well as antagonistic effects of prolactin signaling demonstrate the need for further biological study.

Signals from PRLR crosstalk with other signaling pathways including those activated by estrogens, androgens, and growth factors including the IGFs and TGF- $\alpha(16,27$. This suggests that LFA102 may be particularly effective in combination with other hormonal therapies or molecular targeted drugs. For example, LFA102 potentiated the efficacy of an aromatase inhibitor, letrozole, in a preclinical breast cancer model (19). Autocrine prolactin can activate the oncogenic receptor HER2, and in HER2-positive breast cancers this is associated with increased proliferation and metastasis. Interestingly, the combination of trastuzumab and inhibition of PRLR signaling blocks cellular proliferation $(18,35)$. In another example, a PRLR antagonist augmented the cytotoxic effects of doxorubicin and paclitaxel in preclinical experiments, whereas it was ineffective as a single agent (36). LFA102 in combination with other agents that inhibit the above pathways might therefore be a potential strategy to pursue.

In conclusion, LFA102 up to $40 \mathrm{mg} / \mathrm{kg}$ was well tolerated and showed an acceptable safety profile in Japanese patients. No anti-tumor activity was observed in patients with advanced breast cancer or CRPC when LFA102 was used as a single agent. More studies are needed to understand the role of PRLR-driven signaling cascades in tumor growth, especially with regard to cross-talk between the PRLR pathway and oncogenes, growth factors and hormones. It will also be necessary to develop accurate biomarkers to identify patient subgroups that could benefit from PRLR blockade.

\section{Conflicts of Interest}

H.M. received research grants and honoraria from Bayer Yakuhin, Boehringer Ingelheim, Bristol-Myers Squib, Chugai Pharmaceutical, DaiichiSankyo, Eisai, Kyowa-Kirin, Merck Serono, MSD, Novartis, Ono Pharmaceutical, Pfizer, Sanofi, Takeda Pharmaceutical, and Taiho Pharmaceutical, Eli Lilly; research grants from Asahi-Kasei Pharma, Astellas Pharma, Nippon Shinyaku, Yakult Honsha, CSL, Behring, and Nippon Kayaku; honoraria from Celgene, Ohtsuka Pharmaceutical, Shire Japan, Genomic Health, and Abbvie. Y.A. received research grants and honoraria from Chugai Pharmaceutical Co., Ltd., Kyowa Hakko Kirin Co., Ltd., Nippon Kayaku Co., Ltd., Yakult Honsha Co., Ltd., Mochida Pharmaceutical Co., Ltd., Ono Pharmaceutical Co., Ltd., Taiho Pharmaceutical Co., Ltd., and Daiichi Sankyo Company, Ltd.; research grants from Eisai Co., Ltd.; and honoraria from Eli Lilly Japan K.K., Bristol-Myers Squibb, Sawai Pharmaceutical Co., Ltd, Tsumura \& Co., Shionogi \& Co., Ltd, Novartis Pharma K.K., and Bayer Holding Ltd. outside the submitted work. K.T. received research funding from Pfizer, Daiichi-Sankyo, Eli Lilly, Chugai, AstraZeneca, MSD and Novartis. T.T. is an employee of Novartis Pharma K.K. R.I. is an employee of Novartis Pharmaceuticals Corporation.

\section{Authors' Contributions}

H.M. enrolled and treated patients, interpreted data, and wrote the manuscript; Y.A. and K.T. enrolled and treated patients, interpreted data, and reviewed the manuscript; T.T. reviewed the pharmacokinetic part of the manuscript; R.I. supervised the study concept and design, interpreted data, and reviewed the manuscript.

\section{References}

1 Damiano JS and Wasserman E: Molecular pathways: Blockade of the PRLR signaling pathway as a novel antihormonal approach for the treatment of breast and prostate cancer. Clin Cancer Res 19(7): 1644-1650, 2013. PMID: 23515410. DOI: 10.1158/1078-0432.CCR-12-0138

2 Rose-Hellekant TA, Arendt LM, Schroeder MD, Gilchrist K, Sandgren EP and Schuler LA: Prolactin induces ER $\alpha$-positive and ER $\alpha$-negative mammary cancer in transgenic mice. Oncogene 22(30): 4664-4674, 2003. PMID: 12879011. DOI: 10.1038/sj.onc.1206619

3 Rouet V, Bogorad RL, Kayser C, Kessal K, Genestie C, Bardier A, Grattan DR, Kelder B, Kopchick JJ, Kelly PA and Goffin V: Local prolactin is a target to prevent expansion of basal/stem cells in prostate tumors. Proc Natl Acad Sci USA 107(34): 1519915204, 2010. PMID: 20699217. DOI: 10.1073/pnas.0911651107

4 Wennbo H, Gebre-Medhin M, Gritli-Linde A, Ohlsson C, Isaksson OG and Törnell $\mathrm{J}$ : Activation of the prolactin receptor but not the growth hormone receptor is important for induction of mammary tumors in transgenic mice. J Clin Invest 100(11): 2744-2751, 1997. PMID: 9389738. DOI: 10.1172/JCI119820 
5 Harvey S, Martínez-Moreno CG, Luna M and Arámburo C: Autocrine/paracrine roles of extrapituitary growth hormone and prolactin in health and disease: An overview. Gen Comp Endocrinol 220: 103-111, 2015. PMID: 25448258. DOI: 10.1016/j.ygcen.2014.11.004

6 Levina VV, Nolen B, Su Y, Godwin AK, Fishman D, Liu J, Mor G, Maxwell LG, Herberman RB, Szczepanski MJ, Szajnik ME, Gorelik E and Lokshin AE: Biological significance of prolactin in gynecologic cancers. Cancer Res 69(12): 52265233, 2009. PMID: 19491263. DOI: 10.1158/0008-5472.CAN08-4652

7 Otte JM, Otte C, Beckedorf S, Schmitz F, Vonderhaar BK, Fölsch UR, Kloehn S, Herzig KH and Mönig H: Expression of functional prolactin and its receptor in human colorectal cancer. Int J Colorectal Dis 18(1): 86-94, 2003. PMID: 12458387. DOI: 10.1007/s00384-002-0414-7

8 Tandon M, Coudriet GM, Criscimanna A, Socorro M, Eliliwi M, Singhi AD, Cruz-Monserrate Z, Bailey P, Lotze MT, Zeh H, Hu J, Goffin V, Gittes GK, Biankin AV and Esni F: Prolactin promotes fibrosis and pancreatic cancer progression. Cancer Res 79(20): 5316-5327, 2019. PMID: 31395607. DOI: 10.1158/0008-5472.CAN-18-3064

9 Reynolds C, Montone KT, Powell CM, Tomaszewski JE and Clevenger CV: Expression of prolactin and its receptor in human breast carcinoma. Endocrinology 138(12): 5555-5560, 1997. PMID: 9389544. DOI: 10.1210/endo.138.12.5605

10 Leav I, Merk FB, Lee KF, Loda M, Mandoki M, McNeal JE and Ho SM: Prolactin receptor expression in the developing human prostate and in hyperplastic, dysplastic, and neoplastic lesions. Am J Pathol 154(3): 863-870, 1999. PMID: 10079264. DOI: 10.1016/S0002-9440(10)65333-3

11 Hankinson SE, Willett WC, Michaud DS, Manson JE, Colditz GA, Longcope C, Rosner B and Speizer FE: Plasma prolactin levels and subsequent risk of breast cancer in postmenopausal women. J Natl Cancer Inst 91(7): 629-634, 1999. PMID: 10203283. DOI: $10.1093 /$ jnci/91.7.629

12 Wang DY, Stepniewska KA, Allen DS, Fentiman IS, Bulbrook RD, Kwa HG, De Stavola BL and Reed MJ: Serum prolactin levels and their relationship to survival in women with operable breast cancer. J Clin Epidemiol 48(7): 959-968, 1995. PMID: 7782804. DOI: 10.1016/0895-4356(94)00201-z

13 Holtkamp W, Nagel GA, Wander HE, Rauschecker HF and von Heyden D: Hyperprolactinemia is an indicator of progressive disease and poor prognosis in advanced breast cancer. Int $\mathrm{J}$ Cancer 34(3): 323-328, 1984. PMID: 6480153. DOI: $10.1002 / \mathrm{ijc} .2910340307$

14 Li H, Ahonen TJ, Alanen K, Xie J, LeBaron MJ, Pretlow TG, Ealley EL, Zhang Y, Nurmi M, Singh B, Martikainen PM and Nevalainen MT: Activation of signal transducer and activator of transcription 5 in human prostate cancer is associated with high histological grade. Cancer Res 64(14): 4774-4782, 2004. PMID: 15256446. DOI: 10.1158/0008-5472.CAN-03-3499

15 Li H, Zhang Y, Glass A, Zellweger T, Gehan E, Bubendorf L, Gelmann EP and Nevalainen MT: Activation of signal transducer and activator of transcription-5 in prostate cancer predicts early recurrence. Clin Cancer Res 11(16): 5863-5868, 2005. PMID: 16115927. DOI: 10.1158/1078-0432.CCR-05-0562

16 Clevenger CV, Furth PA, Hankinson SE and Schuler LA: The role of prolactin in mammary carcinoma. Endocr Rev 24(1): 127, 2003. PMID: 12588805. DOI: 10.1210/er.2001-0036
17 Dagvadorj A, Collins S, Jomain JB, Abdulghani J, Karras J, Zellweger T, Li H, Nurmi M, Alanen K, Mirtti T, Visakorpi T, Bubendorf L, Goffin V and Nevalainen MT: Autocrine prolactin promotes prostate cancer cell growth via Janus kinase-2-signal transducer and activator of transcription-5a/b signaling pathway. Endocrinology 148(7): 3089-3101, 2007. PMID: 17412813. DOI: $10.1210 / \mathrm{en} .2006-1761$

18 Yamauchi T, Yamauchi N, Ueki K, Sugiyama T, Waki H, Miki H, Tobe K, Matsuda S, Tsushima T, Yamamoto T, Fujita T, Taketani Y, Fukayama M, Kimura S, Yazaki Y, Nagai R and Kadowaki T: Constitutive tyrosine phosphorylation of ErbB-2 via Jak2 by autocrine secretion of prolactin in human breast cancer. J Biol Chem 275(43): 33937-33944, 2000. PMID: 10938266. DOI: 10.1074/jbc.M000743200

19 Damiano JS, Rendahl KG, Karim C, Embry MG, Ghoddusi M, Holash J, Fanidi A, Abrams TJ and Abraham JA: Neutralization of prolactin receptor function by monoclonal antibody LFA102, a novel potential therapeutic for the treatment of breast cancer. Mol Cancer Ther 12(3): 295-305, 2013. PMID: 23270929. DOI: 10.1158/1535-7163.MCT-12-0886

20 Agarwal N, Machiels JP, Suarez C, Lewis N, Higgins M, Wisinski K, Awada A, Maur M, Stein M, Hwang A, Mosher R, Wasserman E, Wu G, Zhang H, Zieba R and Elmeliegy M: Phase I study of the prolactin receptor antagonist LFA102 in metastatic breast and castration-resistant prostate cancer. Oncologist 21(5): 535-536, 2016. PMID: 27091421. DOI: 10.1634/theoncologist.2015-0502

21 Babb J, Rogatko A and Zacks S: Cancer phase I clinical trials: Efficient dose escalation with overdose control. Stat Med 17(10): 1103-1120, 1998. PMID: 9618772. DOI: 10.1002/(sici)10970258(19980530)17:10<1103::aid-sim793>3.0.co;2-9

22 Neuenschwander B, Branson M and Gsponer T: Critical aspects of the Bayesian approach to phase I cancer trials. Stat Med 27(13): 2420-2439, 2008. PMID: 18344187. DOI: 10.1002/sim.3230

23 Molitch ME: Drugs and prolactin. Pituitary 11(2): 209-218, 2008. PMID: 18404390. DOI: 10.1007/s11102-008-0106-6

24 Madhusoodanan S, Parida S and Jimenez C: Hyperprolactinemia associated with psychotropics - a review. Hum Psychopharmacol 25(4): 281-297, 2010. PMID: 20521318. DOI: 10.1002/hup.1116

25 Scher HI, Halabi S, Tannock I, Morris M, Sternberg CN, Carducci MA, Eisenberger MA, Higano C, Bubley GJ, Dreicer R, Petrylak D, Kantoff P, Basch E, Kelly WK, Figg WD, Small EJ, Beer TM, Wilding G, Martin A and Hussain M: Design and end points of clinical trials for patients with progressive prostate cancer and castrate levels of testosterone: Recommendations of the prostate cancer clinical trials working group. J Clin Oncol 26(7): 11481159, 2008. PMID: 18309951. DOI: 10.1200/JCO.2007.12.4487

26 Sutherland A, Forsyth A, Cong Y, Grant L, Juan TH, Lee JK, Klimowicz A, Petrillo SK, Hu J, Chan A, Boutillon F, Goffin V, Egan C, Tang PA, Cai L, Morris D, Magliocco A and Shemanko CS: The role of prolactin in bone metastasis and breast cancer cell-mediated osteoclast differentiation. J Natl Cancer Inst 108(3): djv338, 2016. PMID: 26586670. DOI: 10.1093/jnci/djv338

27 Shemanko CS: Prolactin receptor in breast cancer: Marker for metastatic risk. J Mol Endocrinol 57(4): R153-R165, 2016. PMID: 27658959. DOI: 10.1530/JME-16-0150

28 Hachim IY, Hachim MY, Lopez VM, Lebrun JJ and Ali S: Prolactin receptor expression is an independent favorable prognostic marker in human breast cancer. Appl Immunohistochem Mol Morphol 24(4): 238-245, 2016. PMID: 26317306. DOI: 10.1097/PAI.000 0000000000178 
29 Motamedi B, Rafiee-Pour HA, Khosravi MR, Kefayat A, Baradaran A, Amjadi E and Goli P: Prolactin receptor expression as a novel prognostic biomarker for triple negative breast cancer patients. Ann Diagn Pathol 46: 151507, 2020. PMID: 3219927. DOI: $10.1016 /$ j.anndiagpath.2020.151507

30 Yamashita H, Nishio M, Ando Y, Zhang Z, Hamaguchi M, Mita K, Kobayashi S, Fujii Y and Iwase H: Stat5 expression predicts response to endocrine therapy and improves survival in estrogen receptor-positive breast cancer. Endocr Relat Cancer 13(3): 885893, 2006. PMID: 16954437. DOI: 10.1677/erc.1.01095

31 Wagner KU and Rui H: Jak2/stat5 signaling in mammogenesis, breast cancer initiation and progression. J Mammary Gland Biol Neoplasia 13(1): 93-103, 2008. PMID: 18228120. DOI: 10.1007/s 10911-008-9062-z

32 Haines E, Minoo P, Feng Z, Resalatpanah N, Nie XM, Campiglio M, Alvarez L, Cocolakis E, Ridha M, Di Fulvio M, Gomez-Cambronero J, Lebrun JJ and Ali S: Tyrosine phosphorylation of Grb2: Role in prolactin/epidermal growth factor cross talk in mammary epithelial cell growth and differentiation. Mol Cell Biol 29(10): 2505-2520, 2009. PMID: 19273609. DOI: 10.1128/MCB.00034-09

33 Nouhi Z, Chughtai N, Hartley S, Cocolakis E, Lebrun JJ and Ali $\mathrm{S}$ : Defining the role of prolactin as an invasion suppressor hormone in breast cancer cells. Cancer Res 66(3): 1824-1832, 2006. PMID: 16452244. DOI: 10.1158/0008-5472.CAN-05-2292
34 Hachim IY, López-Ozuna VM, Hachim MY, Lebrun JJ and Ali $S$ : Concomitant expression of prolactin receptor and TBF $\beta$ receptors in breast cancer: Association with less aggressive phenotype and favorable patient outcome. Int J Mol Sci 20(7): 1640, 2019. PMID: 30987013. DOI: 10.3390/ijms20071640

35 Scotti ML, Langenheim JF, Tomblyn S, Springs AE and Chen WY: Additive effects of a prolactin receptor antagonist, G129R, and herceptin on inhibition of HER2-overexpressing breast cancer cells. Breast Cancer Res Treat 111(2): 241-250, 2008. PMID: 17955362. DOI: 10.1007/s10549-007-9789-z

36 Howell SJ, Anderson E, Hunter T, Farnie G and Clarke RB: Prolactin receptor antagonism reduces the clonogenic capacity of breast cancer cells and potentiates doxorubicin and paclitaxel cytotoxicity. Breast Cancer Res 10(4): R68, 2008. PMID: 18681966. DOI: $10.1186 /$ bcr2129

Received July 21, 2020

Revised July 27, 2020

Accepted July 28, 2020 